\title{
POSISI SURGA BAGI ORANG YANG BERAKHLAK (Kajian terhadap Hadis Riwayat Abu Umamah)
}

\author{
Sitti Syakirah Abu Nawas \\ Program Studi Ilmu Hadis \\ Fakultas Ushuluddin dan Filsafat \\ Universitas Islam Negeri (UIN) Alauddin Makassar \\ Email: sitti.syakirah@gmail.com
}

\section{Abstrak}

Kemuliaan seseorang tidak hanya dilihat dari sisi kuantitas dan kualitas ibadah ritual formal yang ditujukan kepada Allah, melainkan juga dilihat pada perbuatan atau akhlaknya dalam pergaulan sosial. Tulisan ini menguji validitas dan otentisitas hadis yang berbicara mengenai posisi surga bagi orang yang berakhlak, apakah dapat dipertanggungjawabkan hingga ke Nabi Saw., dengan menggunakan teori yang selama ini dikembangkan ulama hadis. Hadis mengenai posisi surga bagi orang yang berakhlak dapat ditemukan di tiga, dari enam, kitab kanonik, yaitu: satu riwayat dari koleksi Abu Daud; satu riwayat dalam catatan al-Tirmidziy; serta satu riwayat lain ditemukan dalam Sunan Ibn Majah. Selebihnya, hadis ini terekam dalam kitab pasca kitab standard (post canonical collection). Berdasarkan teori yang dikembangkan ulama hadis, sanad hadis, dari dua sampel yang diteliti, Abu Daud dan al-Tirmidziy, yang sedang dibahas memiliki status yang beragam. Sanad Abu Daud berstatus shahih li dzatih sedang sanad al-Tirmidziy berkualitas hasan li ghairih. Berdasarkan hasil analisa matan, yang kemudian dibandingkan dengan hasil analisa sanad, dapat dinyatakan bahwa teks hadis yang kemugkinan besar paling dekat dengan teks yang disabdakan Nabi adalah teks yang direkam oleh Abu Daud dalam Sunannya.

Kata Kunci: Akhlak, Surga, Validitas, Otentisitas, Hadis

\section{Pendahuluan}

Dalam Islam, akhlak merupakan salah satu tolok ukur dalam menentukan kemuliaan seseorang. Akhlak mulia merupakan pondasi utama yang dibangun Nabi Saw. untuk memperbaiki masyarakat Jahiliyah yang dikenal memiliki kebudayaan yang sangat terbelakang. 
Masyarakat Jahiliyah adalah contoh nyata bahwa ketiadaan budi pekerti atau akhlak yang baik akan membawa kemerosotan kebudayan dan peradaban manusia.

Di dalam Islam, kemuliaan seseorang tidak hanya dilihat dari sisi kuantitas dan kualitas ibadah ritual formal yang ditujukan kepada Allah, melainkan juga dilihat pada perbuatan atau akhlaknya dalam pergaulan sosial. Hal di atas menunjukkan bahwa Islam bukanlah agama yang eksklusif. Islam senantiasa mengutamakan sisi humanitas, bukan hanya sisi spiritualitas. Keseimbangan antara yang bersifat duniawi (profan) dan ukhrawi (spirit) harus selalu dijaga.

Begitu pentingnya akhlak, dalam salah satu hadis Nabi dinyatakan bahwa Nabi Saw. memberi jaminan posisi surga tertinggi bagi mereka yang berakhlak mulia. Hadis ini tentu mematahkan persepsi masyarakat pada umumnya, yang menganggap bahwa surga sudah bisa dimasuki hanya dengan shalat, puasa, dan ibadah-ibadah ritual lainnya. Padahal tuntunan al-Qur'an yang diterjemahkan Nabi dalam kehidupan nyata mengajarkan pentingnya akhlak. Bahkan, akhlak mulia dapat menjadi tiket untuk masuk dan menempati posisi di level surga tertinggi.

Tulisan ini akan menguji validitas dan otentisitas hadis yang berbicara mengenai posisi surga bagi orang yang berakhlak, apakah dapat dipertanggungjawabkan hingga ke Nabi Saw., dengan menggunakan teori yang selama ini dikembangkan ulama hadis.

\section{Takhrij Hadis Inventarisasi Hadis}

Matan hadis yang menjadi dasar penelitian ini adalah redaksi yang direkam oleh Abu Daud yang diriwayatkan oleh Abu Umamah, sebagai berikut:

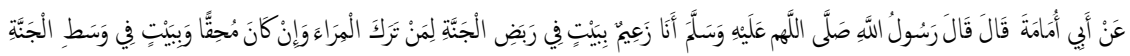

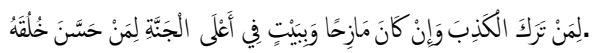


Artinya:

...dari Abu Umamah ia berkata, "Rasulullah Saw. bersabda:

"Aku menjamin rumah di level surga terbawah, bagi seseorang yang meninggalkan perdebatan meskipun benar. (Aku juga menjamin) rumah di tengah surga, bagi seseorang yang meninggalkan kedustaan meskipun sekedar bercanda. (Dan aku juga menjamin) rumah di level surga tertinggi, bagi seseorang yang memperbaiki akhlaknya."

Dalam proses berburu hadis yang kemungkinan tercatat di berbagai kitab hadis lainnya, penulis menggunakan metode takhrij bi al-lafzh dan takhrij bi al-athraf, metode takhrij dengan lafal dan metode takhrij dengan potongan matan hadis.

Untuk metode takhrij bi al-lafzh, penulis melakukan penelusuran melalui lafal rabadha dengan merujuk al-Mu'jam alMufahras li Alfazh al-Hadits al-Nabawiy. Informasi yang penulis peroleh:

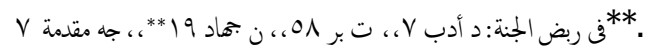

Temuan tersebut mengindikasikan bahwa hadis yang sedang diteliti terdapat dalam: Sunan Abi Daud, Kitab al-Adab, bab ke-tujuh; al-Jami' al-Shahih: Sunan al-Tirmidziy, Kitab al-Birr, no. Bab 58; Sunan al-Nasa'iy, Kitab Jihad, bab 19 dengan beberapa jalur sanad; dan Sunan Ibn Majah, Muqaddimah, bab ke-tujuh dengan beberapa jalur sanad.

Sedang untuk takhrij hadis bi al-athraf, penulis menggali informasi yang bersumber dari sejumlah kutub al-mutn dalam CD ROM al-Maktabah al-Syamilah versi 13 GB. Berikut potongan redaksi hadis yang penulis gunakan, jumlah hadis yang dapat diakses dari potongan tersebut, serta daftar hadis yang sesuai dengan pembahasan:

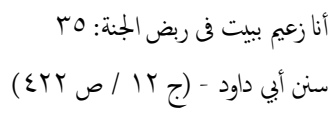




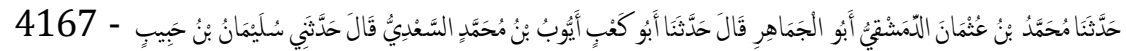

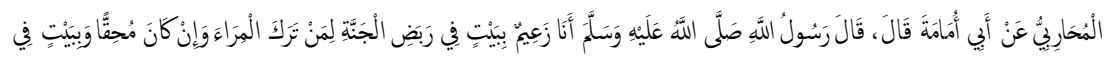

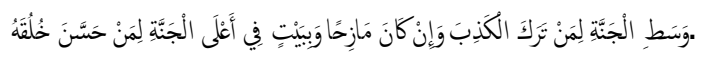

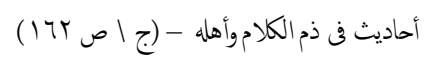

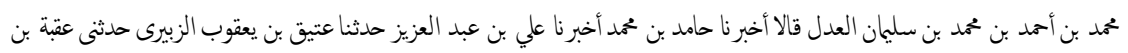

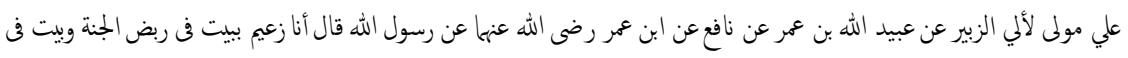

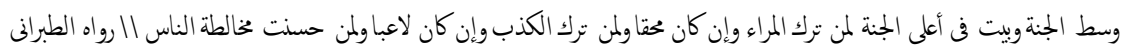

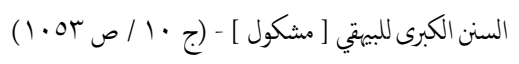

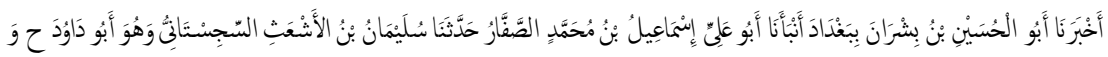

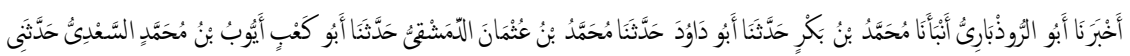

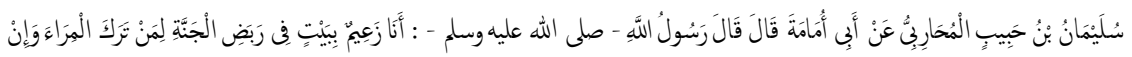

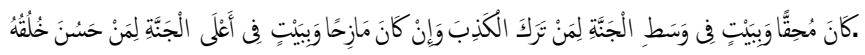

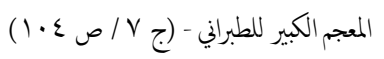

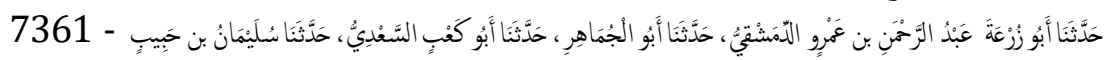

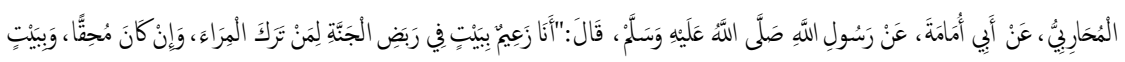

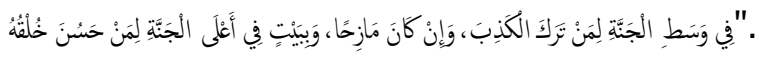

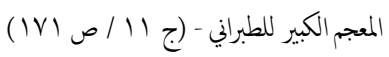

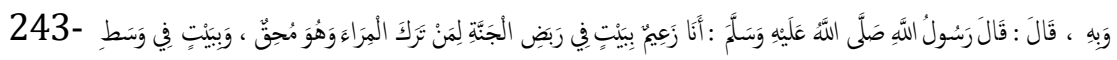

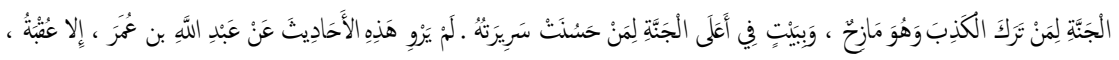

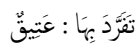

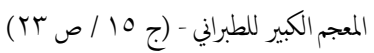

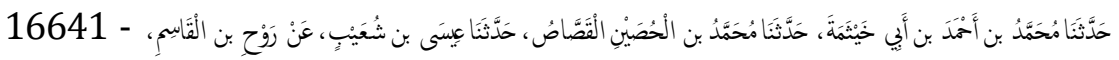

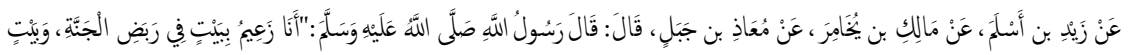

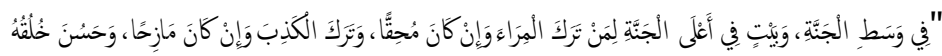

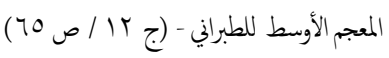

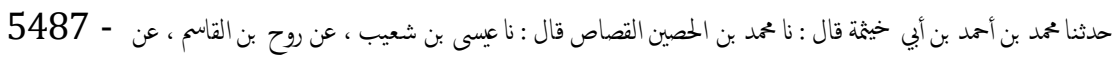

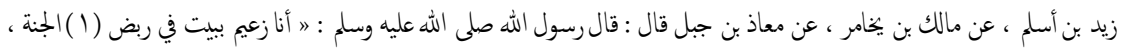

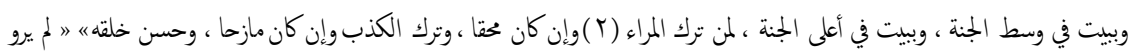

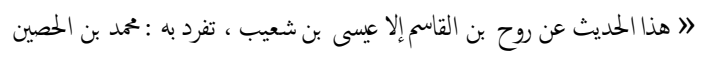

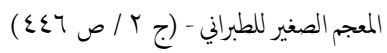




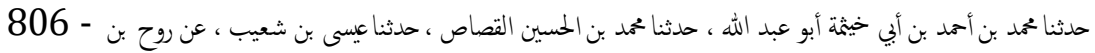

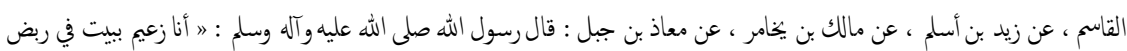

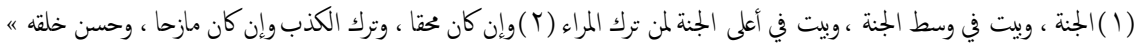

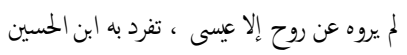

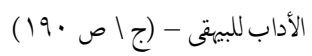
باب ترك المراء وإن كان حقا، وترك الكذب وإن كان مازها

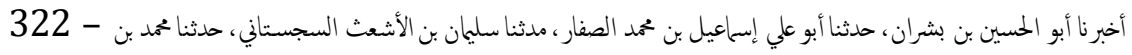

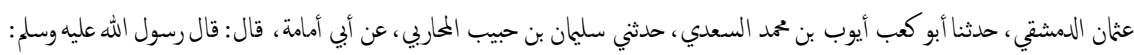

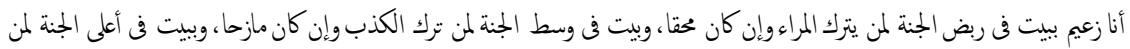

. مسن خلقه.

مسند الشامين للطبراني - (ج 10 ص 199 )

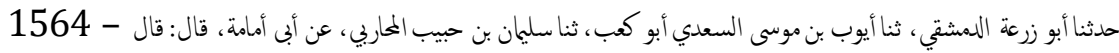

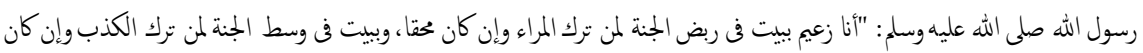

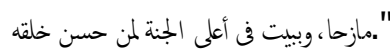

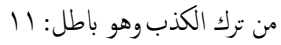

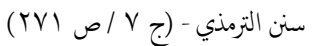

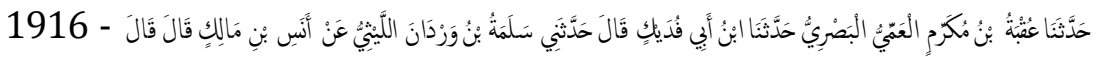

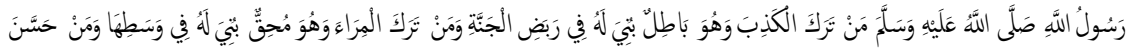

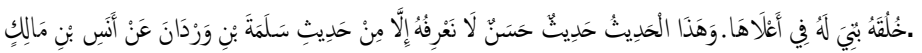

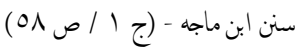

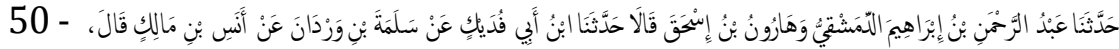

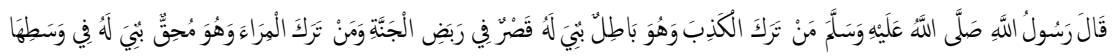

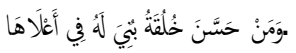

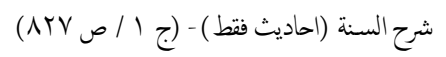

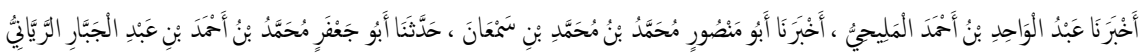

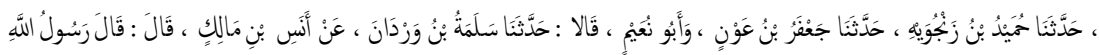

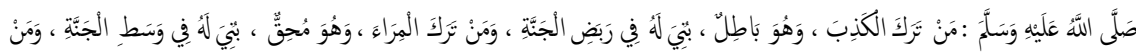

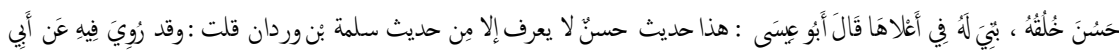
كأمة

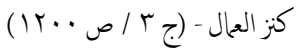




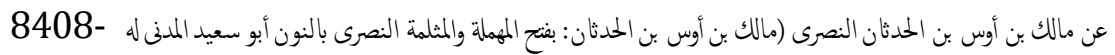

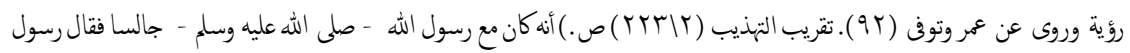

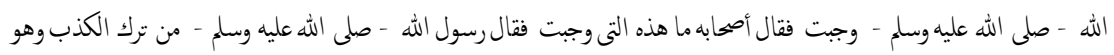

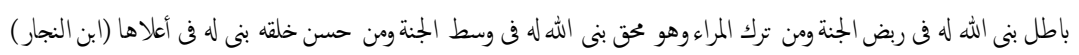

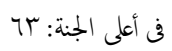

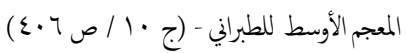

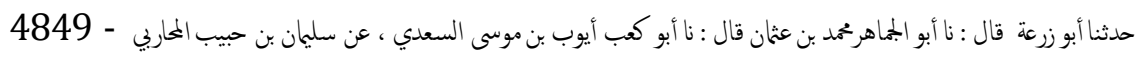

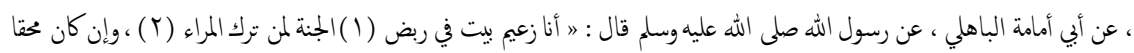

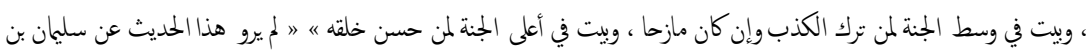
" حبيب إلا أبو كب

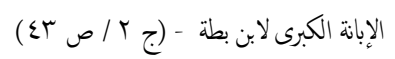

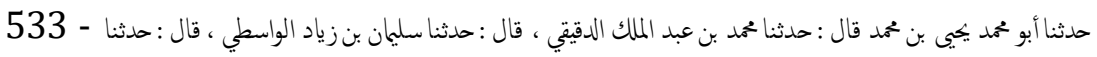

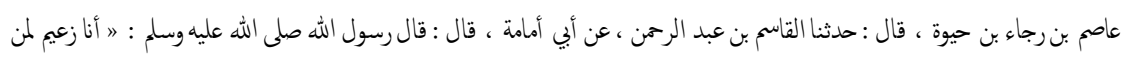

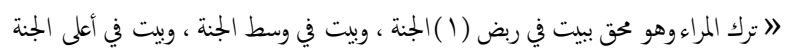

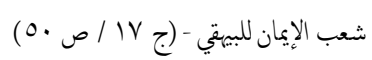

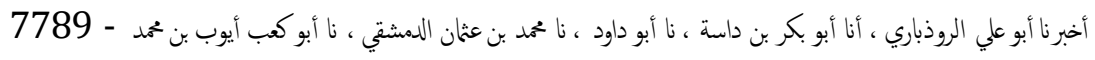

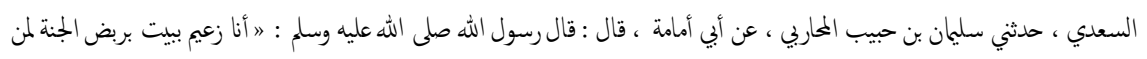

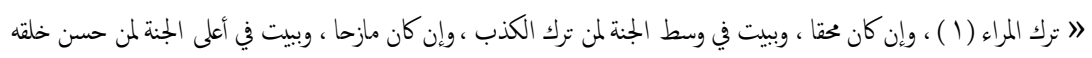
بني له في أعلاها: في ربض الجنة: 90

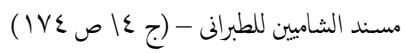

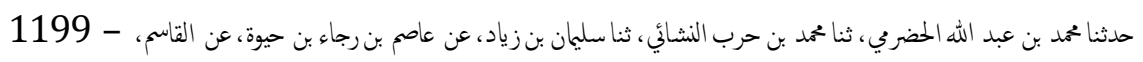

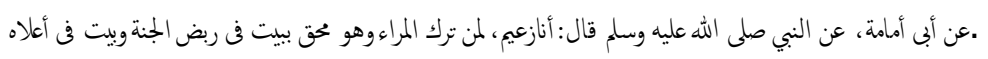

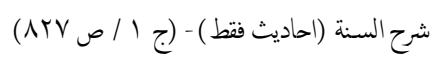

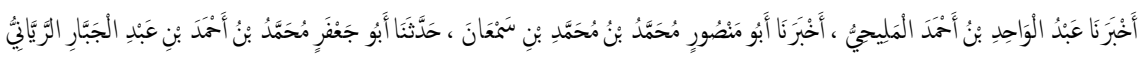

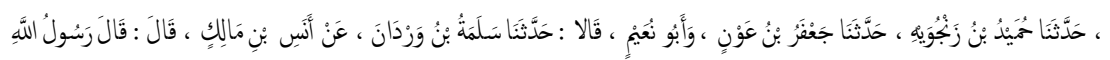

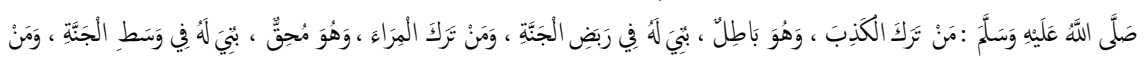


أمامة

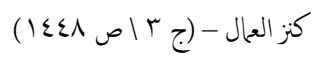




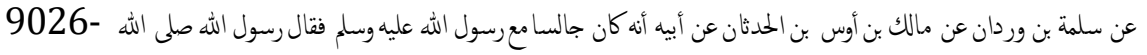

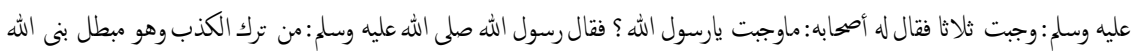

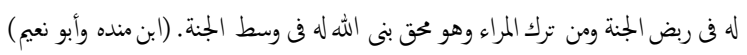
في أعلاها: •r 7

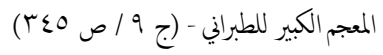

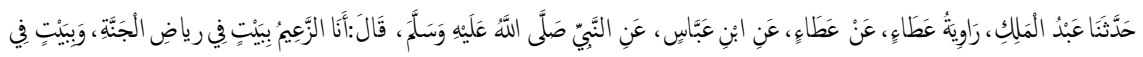

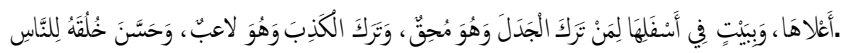

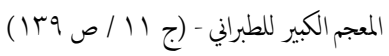

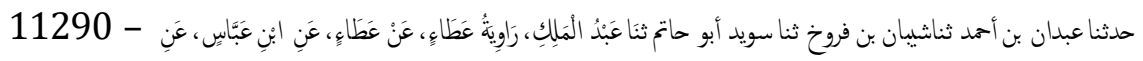

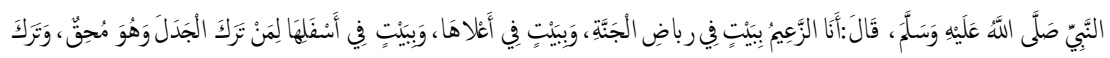

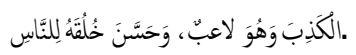

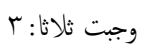

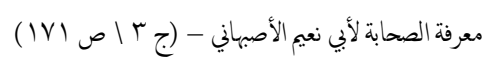

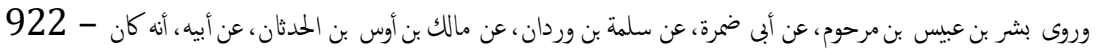

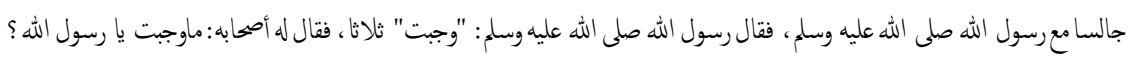

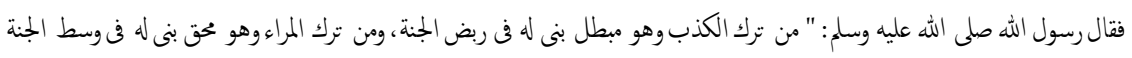
" إبراهيم بن فهد عنه الهول

Menurut hasil survei di atas, diketahui bahwa tidak semua kitab hadis yang tergolong kitab kanonik, kutub al-sittah, memuat hadis "posisi surga bagi orang yang berakhlak". Hadis ini hanya terdapat di dalam tiga dari enam kitab hadis, yaitu: Sunan Abi Daud (1 hadis), Sunan al-Tirmidziy (1 hadis), dan Sunan Ibn Majah (1 hadis). Sementara al-Bukhariy, Muslim, dan al-Nasa'iy, tidak memasukkan hadis ini di dalam masing-masing kitab mereka. Hadis lainnya, penulis peroleh dari koleksi pasca kutab al-sittah (post canonical collection).

\section{a. VARIAN MATAN}

Setelah melakukan inventarisasi hadis, untuk kepentingan analisis yang lebih mendalam, penulis mengelompokkan hadis berdasarkan perbedaan redaksi ke dalam lima varian; sebagai berikut: 


\section{Varian I:}

\begin{tabular}{|c|c|c|}
\hline غخرج & متن & سند \\
\hline أبو داود & 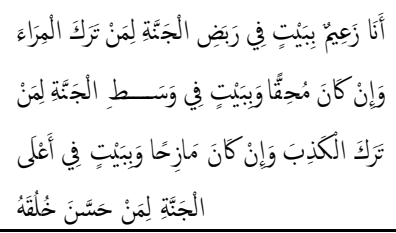 & 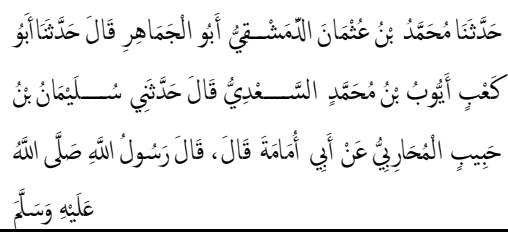 \\
\hline البييقى (سنن & 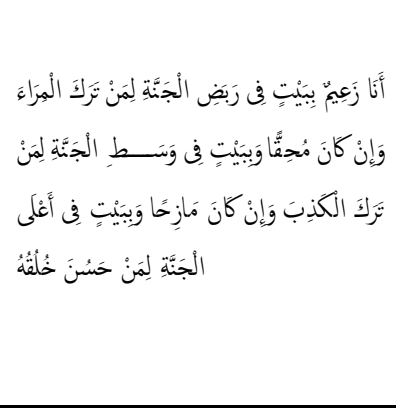 & 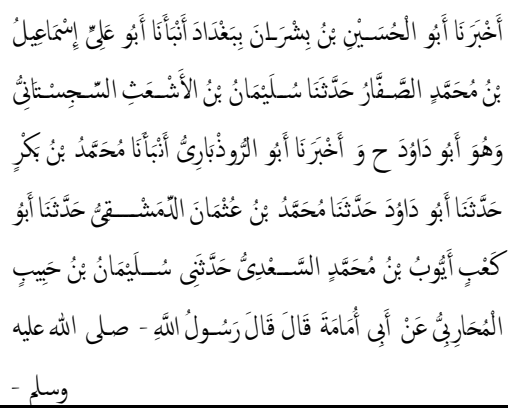 \\
\hline الــــــــى & 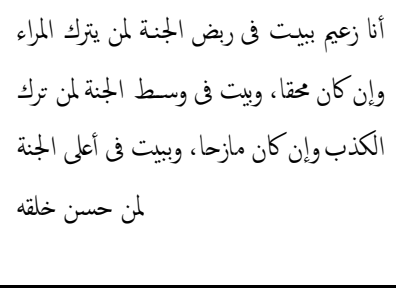 & 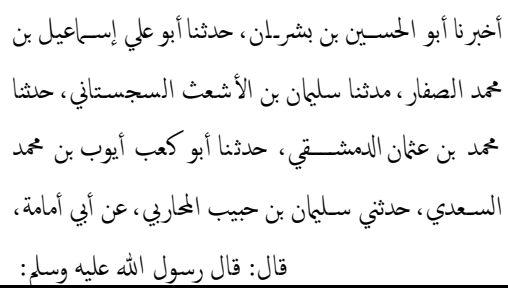 \\
\hline (شــــــــــى & 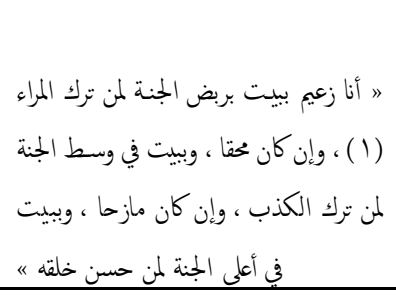 & 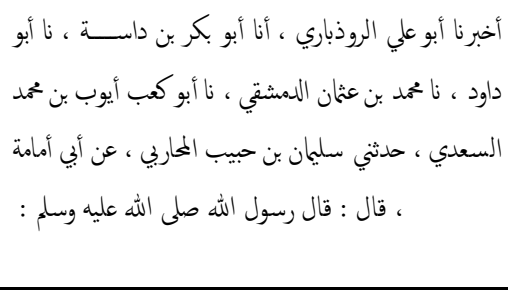 \\
\hline 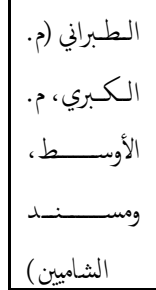 & 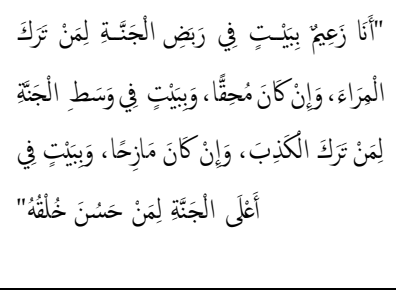 & 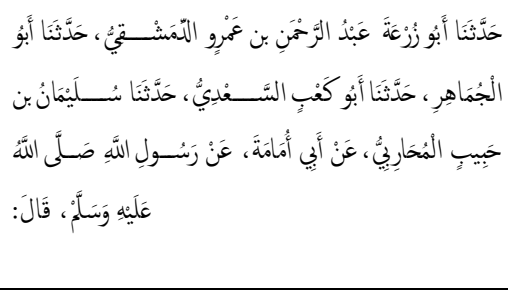 \\
\hline
\end{tabular}




\section{Varian II:}

\begin{tabular}{|c|c|c|}
\hline مخرج & متن & سند \\
\hline ابن بطـة (الإبانة & " أنا زعيم لمن ترك المراء وهو محق بيت في ربض (1) & 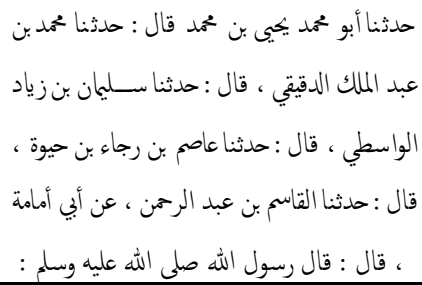 \\
\hline الطبرانى (مســند & أنازعيم، لمن ترك المراء وهو محق ببيت فى ربض الجنة & 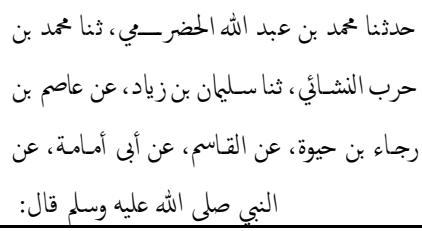 \\
\hline
\end{tabular}

\section{Varian III:}

\begin{tabular}{|c|c|c|}
\hline مخرج & متن & سند \\
\hline الطبراني & 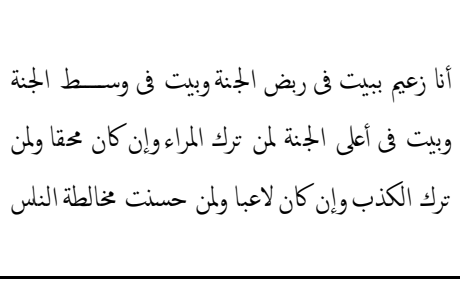 & 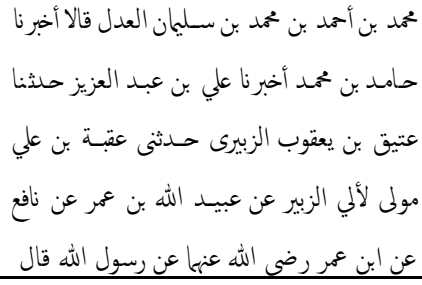 \\
\hline 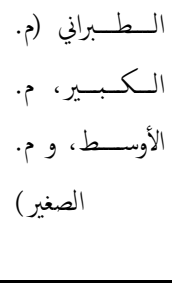 & 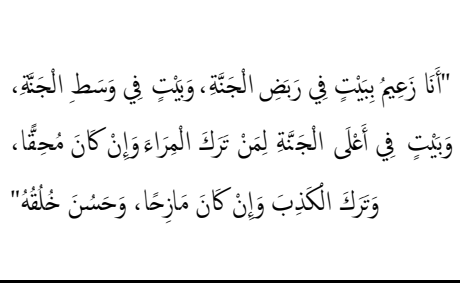 & 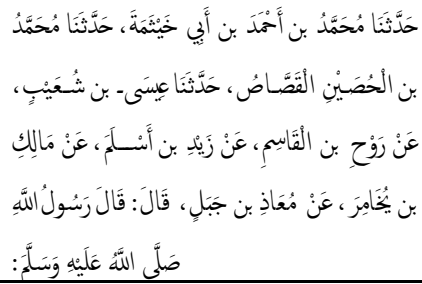 \\
\hline 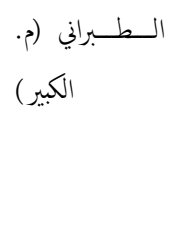 & 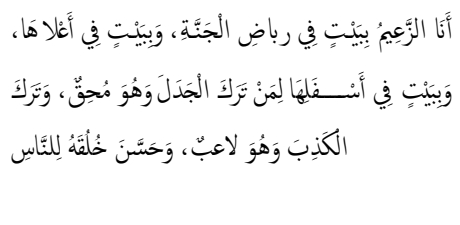 & 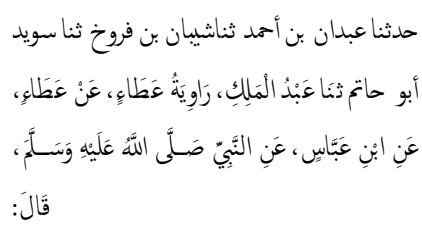 \\
\hline
\end{tabular}




\section{Varian IV:}

\begin{tabular}{|c|c|c|}
\hline مخرجح & متن & سند \\
\hline الترمذي & 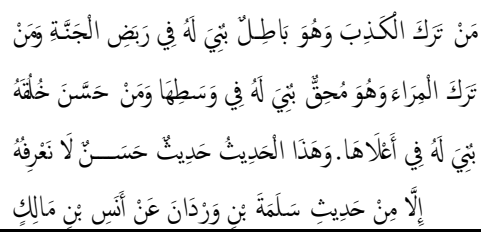 & 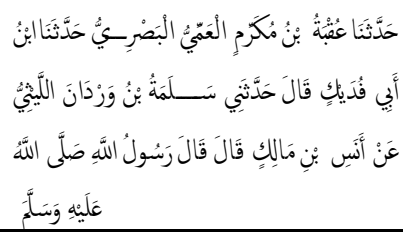 \\
\hline ابن ماجة & 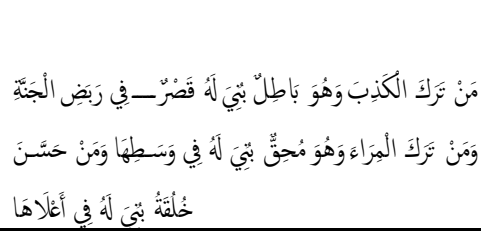 & 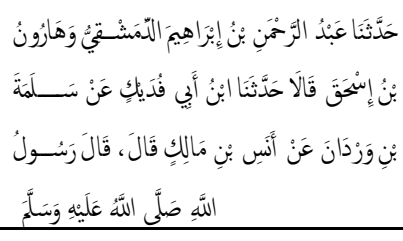 \\
\hline 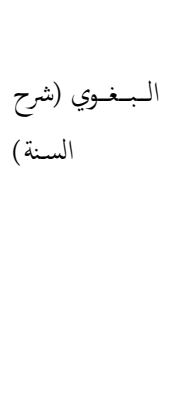 & 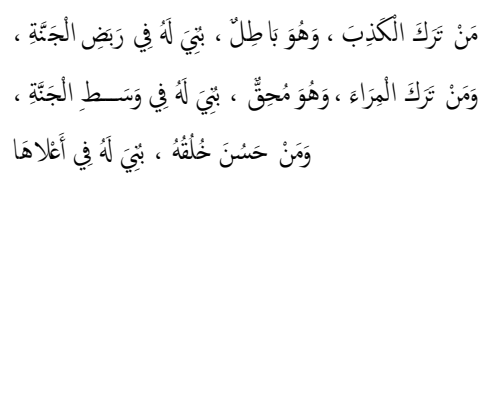 & 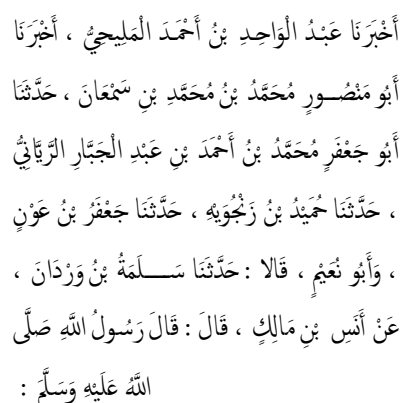 \\
\hline
\end{tabular}

\section{Varian V}

\begin{tabular}{|c|c|c|}
\hline مخرج & متن & سند \\
\hline الهندي & 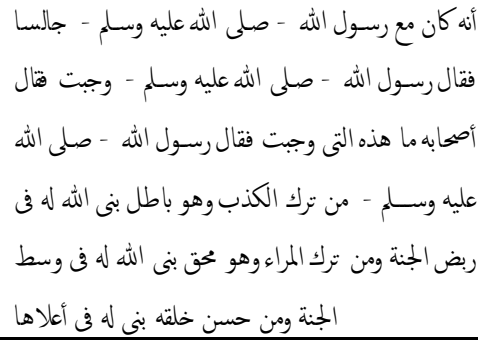 & 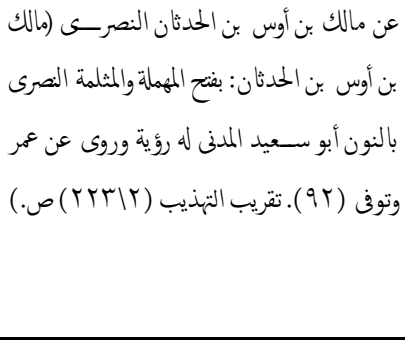 \\
\hline الهندي & من ترك الكذب وهو مبطل بنى الله له في ربض الجنة & 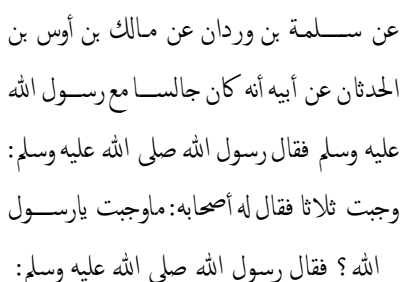 \\
\hline
\end{tabular}




\begin{tabular}{|c|c|c|}
\hline أبو نعيم & من ترك الكذب وهو مبطل بنى له في ربض الجنة، ومن & 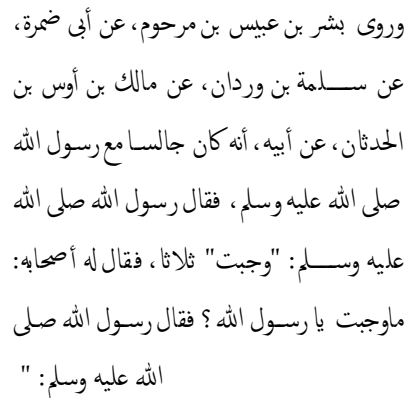 \\
\hline
\end{tabular}

Mengenai penyebab perbedaan redaksional yang tampak pada kutipan hadis di atas, menurut penulis, disebabkan oleh adanya periwayatan secara makna. Argumentasi yang menguatkan kesimpulan itu adalah: pertama, adanya kesamaan materi yang dikandung dalam hadis-hadis tersebut. Kedua, al-Mubarakfuriy, penulis syarah Sunan al-Tirmidziy, ketika menjelaskan pernyataan alTirmidziy yang menyebutkan bahwa وهذا الحديث حديث حسن لا نعرفه إلامن حديث سلمة بن menguraikan bahwa sebenarnya hadis itu juga diriwayatkan oleh Abu Umamah, seperti hadis yang direkam oleh Abu Daud. Menurutnya, salah satu tradisi al-Tirmidziy adalah memberi label hasan terhadap hadis yang berkulitas dha'if yang memiliki syawahid (koraborator), hal ini pun diamini oleh al-Baghawiy dan alAlbaniy. Ketiga, dalam investigasi awal, penulis menemukan bahwa terdapat seorang periwayat yang sama dalam jalur hadis al-Tirmidziy, Ibn Majah, dan selainnya, yang berkualitas dha'if bahkan dinilai mungkar oleh kritikus. Hal ini tentu saja berimplikasi terhadap redaksi hadis yang ia riwayatkan, terlebih karena kedha'ifan periwayat itu berkaitan dengan kedhabithannya.

Peristiwa periwayatan secara makna, bukanlah hal yang langka dalam sejarah periwayatan hadis, dan para ulama hadis pada umumnya dapat menerima hal ini dengan catatan tidak membawa perubahan "makna umum" hadis. 
b. I'tibar

Setelah kegiatan inventarisasi dan pengelompokan hadis berdasarkan varian redaksinya, langkah slanjutnya adalah i'tibar. Untuk mempermudah proses i'tibar diperlukan pembuatan skema untuk seluruh sanad hadis yang diteliti. Dalam pembuatan skema ada tiga hal penting yang perlu diperhatikan, yakni: jalur seluruh sanad, nama-nama periwayat untuk seluruh sanad, dan metode periwayatan yang digunakan masing-masing periwayat.

Dari skema diperoleh informasi bahwa hadis ini diriwayatkan oleh enam orang sahabat, yakni Ibn 'Umar (w. 73/74 H), Mu'adz ibn Jabal (w. 18 H), Ibn 'Abbas (w. 68 H), Abu Umamah (w. 86 H), Anas Ibn Malik (w. 92 H), dan 'Aus ibn al-Hudtsan (w. ?).

Selain keenam sahabat itu, dalam salah satu jalur yang direkam oleh al-Hindiy (lihat skema) terdapat nama Malik ibn 'Aus alHudtsan (w.91/92 H) yang menjadi periwayat pertama. Malik merupakan periwayat yang cukup kontroversial. Kritikus hadis "berdebat" mengenai label yang layak disematkan kepada Malik. Sebagian menempatkannya dalam gerbong sahabat, sebuah posisi prestigious bagi seorang periwayat, sedang lainnya, misalnya alBukhariy, Ibn Hatim, dan Yahyaibn Ma'in menyatakan bahwa ia tidak termasuk dalam jajaran periwayat sahabat. Bagi mereka yang mengklaim Malik al-Hudtsan adalah seorang sahabat, menjadikan informasi mengenai pernah terjadi pertemuan antara Malik dengan Nabi sebagai argumen. Sedang mereka yang bersikukuh mengenai status Malik yang bukan sahabat, berada di level kibar al-tabi'in, berpegang pada informasi keterlambatan Malik memeluk Islam. Selain itu ada juga yang menyatakan bahwa Malik memang pernah bertemu dengan Nabi, namun ia tidak menerima satu pun riwayat darinya, sehingga ia dinilai sebagai periwayat yang sering melakukan irsal. Bekaitan dengan perdebatan tersebut, penulis cenderung "memihak" kepada kritikus yang menyatakan bahwa Malik bukan 
sahabat. Menurut penulis, pertemuan dengan Nabi tidak secara otomatis menjadikan seseorang menyandang gelar sahabat. Salah satu unsur utama yang dinilai adalah pengakuannya terhadap Nabi Saw. dan ajaran yang dibawanya. Walau dalam buku biografi yang penulis kutip tidak disebutkan tahun keislaman Malik, namun ada indikasi kuat bahwa pertemuannya dengan Nabi terjadi ketika ia belum Islam.

Dari masing-masing sahabat, kecuali Abu Umamah, hadis yang diteliti hanya ditransmisikan oleh satu orang tabi'in. Bahkan di beberapa jalur sanad, hal tersebut terlihat hingga ke mukharrij. Dari deskripsi ini bisa ditarik dua catatan guna penelitian lebih lanjut: pertama, ditinjau dari segi kuantitas periwayatnya, hadis posisi manusia yang beretika di surga ini termasuk ke dalam hadis ahad, dalam hal ini masyhur, dan oleh karena itu harus "patuh" pada persyaratan validitas hadis sebelum dijadikan hujjah. Kedua, karena diinformasikan oleh lebih dari satu periwayat mulai dari level pertama (thabaqah sahabat) hingga level terakhir (mukharrij), maka terdapat koroborasi (baik berupa syawahid, di tingkat sahabat, maupun mutaba'ah, di tingkat tabi'in) antara satu riwayat dengan riwayat lainnya (lihat skema).

\section{Validitas Hadis Posisi Surga bagi Orang yang Berakhlak}

a. Validitas Sanad

Dalam ilmu hadis, pengujian kualitas sanad lebih didahulukan dalam proses penelitian, karena pengujian sanad dinilai sebagai pengujian hadis dari perspekstif historis yang berguna untuk mengkritisi teks matan selaku historical report.

Secara garis besar ada tiga unsur yang menjadi pertimbangan dalam meneliti validitas sanad: 1. Kontinuitas sanad; 2. Kredibilitas periwayat ('adl dan dhabth); dan 3. Syadz (kejanggalan) serta 'illah (cacat). 
b. Kontinuitas Sanad

Bila dilihat kembali skema sanad, terkesan bahwa seluruh jalur sanad tersebut bersambung (muttashil), kecuali sanad al-Hindiy dari Malik al-Hudtsan yang telah dijelaskan sebelumnya. Asumsi ini didukung, pertama, dari usia masing-masing periwayat yang memungkinkan mereka untuk bertemu. Kedua, dari lambanglambang periwayatan yang digunakan oleh periwayat yang menggambarkan proses transver riwayat yang umumnya secara langsung dari yang satu ke yang lainnya, yakni menggunakan lambang haddatsana dan haddatsani, kecuali pada thabaqah sebelum sahabat yang menggunakan lambang 'an yang menunjukkan cara penerimaan yang ambigu atau mengandung dua kemungkinan antara mendengar secara langsung atau tidak, khususnya seperti yang ditunjukkan mata rantai sanad yang dicatat oleh Abu Daud melalui jalur Abu Umamah dan al-Tirmidziy melalui Anas ibn Malik.

Mayoritas ulama hadis berpendapat bahwa hadis yang diriwayatkan dengan menggunakan 'an harus dianggap muttashil, kecuali ada bukti yang menunjukkan sebaliknya, bahwa sanad tersebut terputus (munqathi'). Oleh karena itu, mereka menetapkan dua persyaratan bagi periwayat yang menggunakan lafal 'an supaya riwayatnya dapat diterima. Pertama, ada bukti pertemuan antara periwayat yang menggunakan lafal itu dengan periwayat sebelumnya. Kedua, periwayat yang menggunakan lafal 'an bukan orang yang tertuduh mudallis (orang yang suka menyembunyikan cacat hadis). Ketiga, periwayat yang menggunakan lambang 'an adalah periwayat yang dinilai tsiqah.

Untuk membuktikan bahwa sanad hadis ini bersambung serta untuk menjawab keraguan seputar penggunaan lafal 'an yang digunakan oleh sebagian periwayat, akan ditelusuri bagaimana kredibilitas periwayat yang terdapat dalam sanad hadis di atas. 


\section{c. Kredibilitas Periwayat}

Berdasarkan hasil investigasi awal yang penulis lakukan terhadap rijal hadis yang sedang diteliti, khususnya rijal Abu Daud dan alTirmidziy, ditemukan beberapa nama periwayat, baik dari sanad Abu Daud dan al-Tirmidziy, yang masih harus didiskusikan. Untuk kepentingan analisis, penulis mencantumkan biografi para periwayat yang terdapat dalam dua jalur tersebut. Berikut biografi singkatnya, dimulai dari rijal Abu Daud:

\begin{tabular}{|c|c|c|c|c|}
\hline No & Periwayat & Guru & Murid & $\begin{array}{l}\text { Komentar } \\
\text { Kritikus }\end{array}$ \\
\hline 1 & $\begin{array}{l}\text { Muhammad } \\
\text { ibn 'Utsman } \\
\text { al- } \\
\text { Tanwakhiy } \\
\text { (Abu al- } \\
\text { Jamahir) w. } \\
224 \text { H. Ia } \\
\text { berdomisili } \\
\text { di } \\
\text { Damasqus, } \\
\text { Syiria. }\end{array}$ & 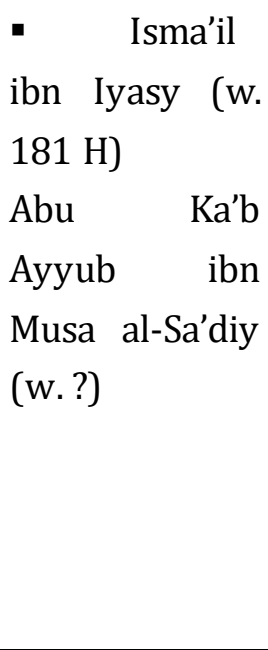 & $\begin{array}{l}\text { - Abu } \\
\text { Daud (w. } \\
275 \mathrm{H} \text { ) } \\
\text { - Abu } \\
\text { Hatim al- } \\
\text { Raziy (w. } \\
277 \text { ) }\end{array}$ & 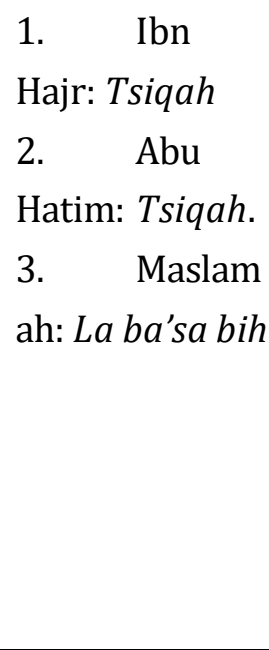 \\
\hline 2 & $\begin{array}{l}\text { Abu Ka'b } \\
\text { Ayyub ibn } \\
\text { Musa al- } \\
\text { Sa'diy. Tidak } \\
\text { terdapat } \\
\text { informasi } \\
\text { mengenai }\end{array}$ & $\begin{array}{l}\text { - Sulaima } \\
\text { n ibn Habib al- } \\
\text { Muharabiy (w. } \\
\text { 126 H) } \\
\text { - 'Abd al- } \\
\text { 'Aziz al- }\end{array}$ & $\begin{array}{l}\text { Muham } \\
\text { mad ibn } \\
\text { 'Utsman } \\
\text { (Abu al- } \\
\text { Jamahir) } \\
\text { (w. 224 } \\
\text { H) }\end{array}$ & $\begin{array}{l}\text { 1. Al- } \\
\text { Raziy: Tsiqah } \\
2 . \quad \text { Ibn } \\
\text { 'Asakir: wa } \\
\text { huwa } \quad \text { shawwab } \\
\text { sha }\end{array}$ \\
\hline
\end{tabular}

${ }^{1}$ Lihat Abu Hatim al-Raziy (al-Raziy), al-Jarh wa al-Ta'dil, juz VIII (Cet. I; Beirut: Dar Ihya al-Turats al-'Arabiy, 1952), h. 25. Lihat juga al-Mizziy, juz III, h. 498. 


\begin{tabular}{|c|c|c|c|c|}
\hline & $\begin{array}{l}\text { tahun } \\
\text { wafatnya, } \\
\text { tapi } \\
\text { disebutkan } \\
\text { bahwa ia } \\
\text { termasuk } \\
\text { dalam level } \\
\text { ke-delapan, } \\
\text { min al- } \\
\text { wustha min } \\
\text { attiba' al- } \\
\text { tabi'in. } \\
\text { Damasqus. }\end{array}$ & $\begin{array}{l}\text { Darawardiy (w. } \\
186 / \\
187 \mathrm{H})\end{array}$ & & \\
\hline 3 & $\begin{array}{l}\text { Sulaiman } \\
\text { ibn Habib al- } \\
\text { Muharabiy } \\
\text { (w. } 126 \mathrm{H} \text { ). } \\
\text { Syam- } \\
\text { Damasqus }\end{array}$ & $\begin{array}{l}\text { - Anas } \\
\text { ibn Malik (w. } \\
92 \mathrm{H}) \\
\text { - Abu } \\
\text { Umamah (w. } \\
86 \mathrm{H}) \\
\text { Abu } \\
\text { Hurairah (w. } \\
57 \mathrm{H})\end{array}$ & $\begin{array}{l}\text { - Abu Ka'b } \\
\text { (w. ?) } \\
\text { - 'Utsman } \\
\text { ibn Abi } \\
\text { al- } \\
\text { 'Atikah } \\
\text { (w. 125 } \\
\text { H) }\end{array}$ & $\begin{array}{l}\text { 1. Yahya } \\
\text { ibn Ma'in, al- } \\
\text { 'Ijliy, dan al- } \\
\text { Nasa'iy: Tsiqah } \\
2 . \quad \text { Al- } \\
\text { Darquthniy: la } \\
\text { ba'sa bih, tabi' } \\
\text { mustaqim. }\end{array}$ \\
\hline 4 & $\begin{array}{l}\text { Shudayya } \\
\text { ibn 'Ajlan } \\
\text { ibn Wahb } \\
\text { (Abu } \\
\text { Umamah al- }\end{array}$ & $\begin{array}{l}\text { - } \\
\text { Sabi } \\
\text { Saw. (w. } 10 \mathrm{H} \text { ) } \\
\text { - 'Aliy ibn } \\
\text { Abi Thalib (w. } \\
40 \mathrm{H})\end{array}$ & $\begin{array}{l}\text { - Salim ibn } \\
\text { 'Amir al- } \\
\text { Khabariy } \\
\text { (w. } 130 \\
\text { H) }\end{array}$ & $\begin{array}{l}1 . \quad \text { Ibn } \\
\text { Hibban: Kana } \\
\text { ma'a 'Aliy } f \text { al- } \\
\text { Shiffin }\end{array}$ \\
\hline
\end{tabular}

${ }^{2}$ Lihat Abi 'Abdullah Muhammad ibn Ahmad ibn 'Utsman al-Dzahabiy, Mizan al-I'tidal fi Naqd al-Rijal (Dar al-Fikr), h. 294. Lihat juga al-Raziy, op. cit., juz II, h. 258; al-Mizziy, op. cit., juz XI, h. 383. 


\begin{tabular}{|l|l|l|l|l|}
\hline Bahiliy) (w. & - & Mu'adz & - Sulaiman \\
86 H). Syam. & ibn Jabal (w.18 & ibn & \\
& H) & Habib al- & Muharab \\
& & iy (w. & \\
& & & $126 \mathrm{H})$ & \\
\hline
\end{tabular}

Rijal al-Tirmidziy:

\begin{tabular}{|c|c|c|c|c|}
\hline No & Periwayat & G u r u & Murid & $\begin{array}{c}\text { Komentar } \\
\text { Kritikus }\end{array}$ \\
\hline 1 & $\begin{array}{lc}\text { 'Uqbah } & \text { ibn } \\
\text { Mukrim } & \text { ibn } \\
\text { Aflah } & \text { al- } \\
\text { 'Ammiy } & \text { al- } \\
\text { Malikiy } & \text { (w. } \\
250 & \text { H). } \\
\text { Bashrah } & \end{array}$ & $\begin{array}{l}\text { - Ibn Abi } \\
\text { Fudaik (w. } 200 \\
\text { H) } \\
\text { - Wahb } \\
\text { ibn Jarir ibn } \\
\text { Hazim }\end{array}$ & 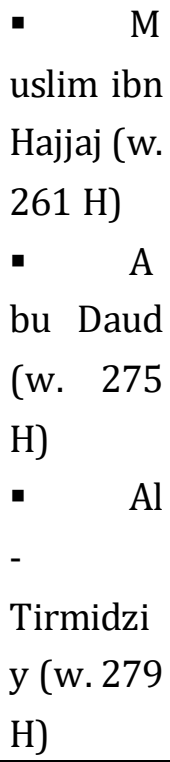 & $\begin{array}{l}\text { 1. Al- } \\
\text { Nasa'iy: Tsiqah } \\
\text { 2. Ibn } \\
\text { Hajar: Tsiqah } \\
\text { 3. Al- } \\
\text { Dzahabiy: al- } \\
\text { Hafizh. }\end{array}$ \\
\hline 2 & $\begin{array}{l}\text { Muhammad } \\
\text { ibn Ism'il ibn } \\
\text { Muslim ibn } \\
\text { Abi Fudaik } \\
\text { (w. } 200 \text { H). } \\
\text { Madinah }\end{array}$ & $\begin{array}{l}\text { - Salama } \\
\text { h ibn Wardan } \\
\text { (w. }-150 \mathrm{H}) \\
\text { - Al- } \\
\text { Dhahak b. }\end{array}$ & $\begin{array}{l}\text { - 'U } \\
\text { qbah b. } \\
\text { Mukrim } \\
\text { (w. } 250 \\
\text { H) }\end{array}$ & $\begin{array}{l}\text { 1. Al- } \\
\text { Nasa'iy: laisa } \\
\text { bihi ba's } \\
\text { 2. Ibn } \\
\text { Ma'in:tsiqah }\end{array}$ \\
\hline
\end{tabular}

${ }^{3}$ Ibid., juz XIII, h. 158-160. Lihat juga Ibn Hajr al-'Asqalaniy, al-Ashabah fi Tamyiz al-Shahabah, jil. III (Cet. I; Beirut: Dar al-Jil, 1992), h. 420-421. 


\begin{tabular}{|c|c|c|c|c|}
\hline & & $\begin{array}{l}\text { ‘Utsman al- } \\
\text { Hazamiy (w. ?) }\end{array}$ & $\begin{array}{l}\text { - Ib } \\
\text { rahim } \\
\text { ibn } \\
\text { Munzir } \\
\text { al- } \\
\text { Hazamiy } \\
\text { (w. } 236 \\
\text { H) }\end{array}$ & $\begin{array}{l}3 . \quad \text { Ibn } \\
\text { Sa'd: } \quad \text { kana } \\
\text { katsir } \\
\text { lal-hadisa }\end{array}$ \\
\hline 3 & 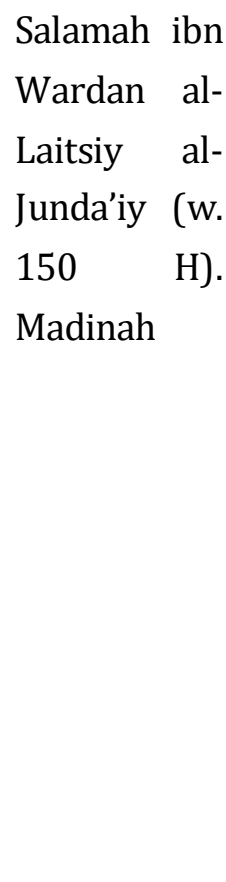 & $\begin{array}{l}\text { - Anas } \\
\text { ibn Malik (w. } 92 \\
\text { H) } \\
\text { - Malik } \\
\text { ibn 'Aus al- } \\
\text { Hudtsan (w. } \\
91 / 92 \mathrm{H} \text { ) }\end{array}$ & $\begin{array}{lr}\text { - Ja } & \text { Jar ibn } \\
\text { ffar } & \text { 'Aun (w. } \\
\text { 206/207 } \\
\text { H) } \\
\text { - } \quad \text { Ib } \\
\text { n } \quad \text { Abi } \\
\text { Fudaik } \\
\text { (w. } 200 \\
\text { H) }\end{array}$ & $\begin{array}{l}\text { 1. Abu } \\
\text { Daud dan al- } \\
\text { Nasa'iy: dha'if } \\
\text { 2. Yahya } \\
\text { ibn Ma'in: laisa } \\
\text { bi sya'in } \\
\text { 3. Ahmad } \\
\text { b Shalih: huwa } \\
\text { 'indiy tsiqah, } \\
\text { hasanal-hadits } \\
\text { 4. Al- } \\
\text { Hakim: } \\
\text { haditsuhu 'an } \\
\text { Anas Manakir } \\
\text { Aktsaruha }\end{array}$ \\
\hline 4 & $\begin{array}{ll}\text { Anas ibn } \\
\text { Malik ibn } \\
\text { Nadhr ibn } \\
\text { Dhamdham } \\
\text { ibn Zaid ibn } \\
\text { Hiram ibn } \\
\text { Jundab ibn } \\
\text { 'Amir ibn }\end{array}$ & $\begin{array}{l}\text { - } \\
\text { Saw. } \\
\text { - } \quad \text { Abu } \\
\text { Bakr al-Shiddiq } \\
\text { (w. 13 H) } \\
\text { - Fatima } \\
\text { h al-Zahra (w. } \\
11 \mathrm{H})\end{array}$ & $\begin{array}{l}- \\
\text { haq b } \\
\text { 'Abdulla } \\
\text { h ibn Abi } \\
\text { Thalhah } \\
\text { (w. } 132 \\
\text { H) }\end{array}$ & $\begin{array}{lr}\text { Saat } & \text { Anas } b \\
\text { Malik } & \text { wafat } \\
\text { Abu } & \text { al- } \\
\text { Mu'tamar } \text { (w. } \\
+100 \quad \mathrm{H}) \\
\text { mengungkapka } \\
\text { n: } \quad \text { telah }\end{array}$ \\
\hline
\end{tabular}




\begin{tabular}{|l|ll|l|l|l|}
\hline Ginam & (w. \\
92 & H). & & - & berpulang \\
Madinah & & Salamah & separuh ilmu. \\
& & b & \\
& & Wardan & \\
& & (w. -150 & \\
& & H) & \\
\hline
\end{tabular}

Demikianlah biografi singkat di atas menginformasikan bahwa rijal Abu Daud "aman" dari kritikan negatif para kritikus. Pujian dengan kualitas terendah yang diberikan sebagian ulama adalah la ba'sa bih yang ditujukan kepada dua orang periwayat, Abu al-Jamahir dan Sulaiman al-Muharabiy. Walaupun sebagian kalangan memberi label la ba'sa bih kepada mereka, yang merupakan salah satu istilah yang berimplikasi hasan, namun karena penilaian tersebut hanya diberikan oleh masing-masing satu orang kritikus, sedang kritikus lainnya mengklaim periwayat itu tsiqah, maka penulis lebih cenderung menilai keduanya tsiqah.

Dari data mengenai tempat berdomisili, tahun wafat, serta pengakuan guru-murid dari masing-masing periwayat dalam jalur Abu Daud, memberikan indikasi kuat bahwa mereka pernah bertemu dan melakukan proses periwayatan. Hal ini menjadi dasar kesimpulan penulis bahwa seluruh lambang periwayatan yang digunakan dalam jalur sanad Abu Daud dapat dipertanggungjawabkan, termasuk 'an yang digunakan dalam transver riwayat antara Sulaiman ibn Habib dan Abu Umamah. Berdasaran informasi di atas, dapat dinyatakan bahwa sanad Abu Daud muttashil.

Berbeda halnya dengan sanad Abu Daud di atas, dalam mata rantai periwayatan yang direkam al-Tirmidziy, sebagaimana disebutkan sebelumnya, terdapat seorang periwayat yang meragukan tingkat kredibilitasnya, yaitu Salamah ibn Wardan. Dalam salah satu kitikan disebutkan bahwa kebanyakan hadis yang Salamah ibn 
Wardan klaim ia terima dari Anas ibn Malik berstatus mungkar, yaitu hadis yang diriwayatkan oleh seseorang yang tidak memenuhi syarat sebagai seorang periwayat hadis, kemudian hadisnya bertentangan dengan yang diriwayatkan oleh periwayat yang tsiqah. Hadis yang diteliti merupakan bukti kebenaran penilaian kritikus tersebut, karena riwayat Salamah di atas bertentangan dengan hadis yang dipublikasikan oleh Abu Daud yang kesemua periwayatnya dilabeli positif oleh kritikus hadis.

Berkaitan dengan lafal 'an yang digunakan oleh Salamah ibn Wardan, menurut penulis, ada kemungkinan ia memang menerima hadis tersebut dari Anas ibn Malik, tapi karena keterbatasan dari sisi kedhabithan, maka ia meriwayatkan hadis tersebut dengan redaksi yang berbeda secara signifikan dengan redaksi Anas ibn Malik. Namun asumsi ini sulit dibuktikan karena tidak adanya periwayat lain yang menginformasikan hadis ini dari Anas kecuali Salamah. Namun, bila asumsi ini ditarik ke wilayah persambungan sanad, maka akan dijawab bahwa hadis ini gair muttashil (tidak bersambung) karena terdapat seorang periwayat yang tidak dhabth yaitu Salamah. Sehingga dapat dinyatakan pula bahwa lafal 'an yang digunakan Salamah untuk menggambarkan proses penerimaan hadisnya tidak dapat dipertanggungjawabkan, walaupun dari biografinya diketahui bahwa ia hidup sezaman, sedomisili, dan ada pengakuan guru-murid antara ia dan Anas.

\section{d. Syadz dan 'illat}

Secara sederhana, syadz dapat dipahami sebagai kelainan yang disebabkan pertentangan riwayat antara seseorang yang tsiqah dengan riwayat orang tsiqah lainnya. Atau dengan kata lain, pertentangan riwayat yang terjadi antara periwayat yang dikenal tsiqah dengan riwayat yang bersumber dari periwayat tsiqah lainnya. Dari pengertian ini, penulis menyimpulkan bahwa penelitian syadz 
untuk sanad berbanding lurus dengan penelitian syadz untuk matan, sehingga tidak dapat dipisahkan. Oleh karena itu, penelitian syadz akan penulis ulas, sekaligus, di bagian pembahasan validitas matan.

Tidak seperti syadz, meneliti kemungkinan terjadinya 'illah pada sanad, menurut penulis, dapat dilakukan secara independen, tanpa bergantung pada penelitian 'illah pada matan.

Dalam teori ilmu hadis, umumnya dinyatakan bahwa 'illah pada sanad kebanyakan berbentuk sanad yang tampak bersambung dan marfu', ternyata bersambung tapi mauquf, dan terjadi kesalahan penyebutan nama periwayat.

Bila diamati skema hadis di atas (lihat skema), terkesan bahwa seluruh sanadnya bersambung sampai kepada Nabi. Namun, bila ditelusuri lebih jauh, terdapat sanad yang mursal, yaitu sanad yang dikoleksi al-Hindiy yang menyebutkan Malik langsung menerima hadis tersebut dari Nabi, padahal, sebagaimana penjelasan sebelumnya, Malik dinyatakan tidak pernah menerima hadis langsung dari Nabi Saw.

Analisis di atas menghasilkan kesimpulan bahwa dari segi sanad, hadis-hadis tentang posisi surga bagi orang yang beretika, khususnya, untuk jalur Abu Daud berkualitas shahih li dzatih, sedang untuk jalur al-Tirmidziy berkualitas dha'if. Kedha'ifan jalur alTirmidziy disebabkan salah seorang periwayat yang dinilai negatif dari sisi kapasitas intelektualnya. Karena adanya dukungan dari jalur Abu Daud yang berkualitas sahih, maka status sanad al-Tirmidziy "tertolong" dan naik ke level hasan lighairih.

\section{e. Validitas Matn}

Menurut prosedur ilmu hadis ada dua langkah yang harus ditempuh untuk membuktikan keabsahan suatu matan hadis: pertama, meneliti susunan lafal (wording of text) dan kedua, meneliti kandungan materinya (content of text). Yang pertama, dalam istilah 
ilmu hadis, berkaitan dengan kemungkinan 'illah, sedang yang kedua berkenaan dengan kemungkinan syadz. Sebagian kalangan menilai bahwa langkah ini sifatnya relative, tergantung pada kondisi matan yang dihadapi. Artinya, suatu matan bisa saja terbukti dha'if cukup hanya dari kerancuan redaksinya; atau cukup hanya dengan melihat adanya pertentangan dengan ayat al-Qur'an, misalnya, atau dari kedua-duanya. Namun, dalam makalah ini, penulis akan menganalisis keduanya.

Susunan Lafal (Wording of Text):

Kemungkinan Terdapat 'Illah

Yang harus dicermati dalam upaya mengidentifikasi terjadinya 'illah adalah: matan yang mengandung idraj (sisipan), terdapat ziyadah (tambahan), terjadi pertukaran letak keberadaan penggal lafal atau kalimat (maqlub), terjadi pertentangan yang tidak dapat dikompromikan (idhtirab), dan terjadi kerancuan lafal dan penyimpangan makna yang jauh dari subtansi.

Dalam bagian pengelompokan hadis berdasarkan variannya terlihat bahwa hadis posisi surga bagi orang yang berakhlak memiliki beberapa varian matan, dengan karakteristik yang beragam. Keragaman ini bukan hanya ditemukan dari periwayat yang berbeda, tapi juga redaksi yang bersumber dari periwayat yang sama.

Pertanyaannya, apakah keragaman itu dapat dipertanggungjawabkan orisinalitasnya sampai kepada Nabi sebagai nara sumber utama?

Salah satu koleksi hadis tentang posisi surga bagi orang yang berakhlak adalah yang bersumber dari Abu Daud yang berjalur Muhammad ibn 'Utsman Abu al-Jamahir (w. 224 H) - Ayyub ibn Muhammad Abu Ka'b (w. ?) - Sulaiman ibn Habib (w. 126 H) - Abu Umamah (w. 86 H). Versi hadis dari jalur inilah yang akan dijadikan titik tolak penelitian matan. Matannya sebagai berikut: 


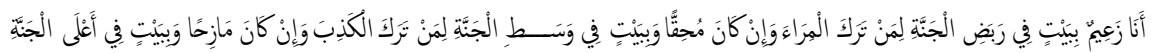

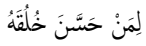

Versi ini juga direkam oleh al-Baihaqiy (w. $458 \mathrm{H}$ ) dari dua orang sekaligus, yaitu:

Jalur Abu al-Husain ibn Basyran - Muhammad ibn Bakr - Abu

Daud

Jalur Abu 'Aliy al-Rudzbariy - Isma'il ibn Shafar - Abu Daud

Dua jalur ini direkam beberapa kali oleh al-Baihaqiy. Di Sunan al-Kubra, ia menyampaikan kedua jalur ini sekaligus dengan cara tahwil. Sedang di al-Adab ia hanya merekam jalur Abu al-Husain ibn Basyran, begitu juga di Sya'b al-Iman, ia hanya mencatat jalur yang bersumber dari Abu 'Aliy al-Rudzbariy.

Selain al-Baihaqiy, versi ini juga dikoleksi oleh al-Thabraniy, dengan jalur Abu Zur'ah- al-Rudzbariy - Muhammad ibn 'Utsman Abu al-Jamahir.

Bila dibandingkan antara versi Abu Daud, al-Baihaqiy, dan alThabraniy, sekilas tidak terdapat perbedaan redaksi sama sekali. Namun bila diamati secara seksama terlihat redaksi al-Baihaqiy , Abu 'Aliy al-Rudzbariy, berbeda dengan versi yang bersumber dari kolektor hadis lainnya yang digunakan adalah fi, fi rabadh al-jannah, perbedaan kecil ini, menurut hemat penulis, kemungkinan bukan dilakukan oleh periwayat hadis, tapi diakibatkan oleh kekeliruan dalam penyalinan.

Versi lain yang dinyatakan bersumber dari Abu Umamah adalah versi yang berjalur:

Abu Muhammad (Yahya ibn Muhammad - Muhammad ibn 'Abd al-Malik - Sulaiman ibn Ziyad - 'Ashim ibn Raja' - alQasim ibn 'Abd al-Rahman - Abu Umamah

Versi ini direkam oleh dua penghimpun hadis, al-Thabraniy (w.360 H) dan Ibn Baththah (w. 387 H). Dalam versi Ibn Baththah, bila 
dibandingkan dengan teks Abu Umamah sebelumnya, terdapat pengurangan diktum li man tarak al-kadzib wa in kana mazihan dan li man hasuna huluqahu. Selain itu, dalam teks yang pertama, lafal bi baitin fi rabadh al-jannah mendahului lafal li man tarak al-mira-a sedang dalam varian ke-dua ini lafal li man tarak al-mira-a bertukar posisi dengan bi baitin fi rabadh al-jannah. Perbedaan lainnya adalah dalam varian I disebutkan wa in kana muhiqqan, sedang di varian II wa huwa muhiqqun. Namun perbedaan ini lebih kepada perbedaan pembahasaan saja, tidak sampai merubah makna umum hadis. Berbeda halnya dengan peghilangan beberapa diktum yang ada dalam teks hadis, mengakibatkan perubahan kandungan teks secara signifikan. Hadis yang dipublikasikan Ibn Baththah mengesankan Nabi hanya memberikan garansi berupa hunian di tiga level surga bagi orang yang menghindari perdebatan saja. Dari sini dapat disimpulkan bahwa hadis Ibn Baththah mengandung 'illah. Al-Qasim ibn 'Abd alRahman disinyalir merupakan periwayat yang menyebabkan perubahan yang ada dalam matan. Kesimpulan ini didasari atas informasi yang menyatakan bahwa ia termasuk periwayat yang kerap meriwayatkan hadis garib, dan termasuk periwayat yang banyak disoroti kemampuan intelektualnya yang dianggap lemah.

Versi teks yang dicatat al-Thabraniy memiliki pola yang sama dengan versi Ibn Baththah. Perbedaannya adalah pengurangan diktum wa bait fi wasath al-jannah, serta penggunaan kalimat fi a'lahu untuk mengganti fi a'la al-jannah. Setelah jalur sanadnya dibandingkan, terlihat bahwa kemungkinan besar yang melakukan pengurangan dan penggantian lafal adalah Muhammad ibn Harb alNasya-iy. Dari sini dapat disimpulkan bahwa versi teks ini pun mengandung 'illah dan syadz.

Beralih ke varian ke-tiga. Bila diamati, terlihat bahwa struktur teksnya berbeda dengan struktur hadis varian pertama. Namun, identik dari segi subtansinya. Ada tiga riwayat dalam varian ini, 
kesemuanya bersumber dari al-Thabraniy. Ketiga versi ini memiliki tiga jalur sanad yang sama sekali berbeda satu sama lain (lihat varian III). Perbedaan struktur yang paling menyolok dari kedua varian ini adalah bila di varian I penyebutan level surga langsung dirangkaikan dengan pencantuman prilaku yang membawa ke level tersebut, maka di varian III ketiga level surga disebutkan terlebih dahulu, kemudian hal-hal yang menyebabkan manusia menempati tiap level itu disebutkan belakangan.

Dalam versi pertama al-Thabraniy, kata mazihan diganti menjadi la'iban. Begitu juga dengan li man hasunat mukhalithatuhu alnas yang mewakili li man hasuna khuluqahu. Perbedaan pengungkapan itu, tidak mengakibatkan perubahan teks hadis secara subtantif. Penulis kesulitan untuk mengidentifikasi secara pasti periwayat yang melakukan perubahan tersebut. Namun, kemungkinan dilakukan oleh periwayat-periwayat dari lini tengah hingga terakhir sebelum al-Thabraniy. Jadi antara 'Uqbah ibn 'Aliy (w. ?) hingga Muhammad ibn Ahmad ibn Muhammad ibn Sulaiman (w.?). Walaupun, jika dibandingkan dengan versi pertama, terjadi pertukaran posisi beberapa penggalan kalimat dalam redaksi hadis, namun pertukaran tersebut tidak menyebabkan pertentangan subtansi. Oleh karena itu, versi ini tidak ber'illah.

Mengenai versi al-Thabraniy yang ke-dua, perbedaannya dengan varian pertama, selain perubahan posisi kalimat, adalah tidak dtampilkannya lafal li man sebelum hasuna khuluqahu. Sebagaimana versi pertama, versi ini juga tidak mengandung 'illah karena perbedaan redaksi tidak melahirkan subtansi yang melenceng dari subtansi umum hadis.

Versi ketiga adalah penghilangan satu diktum, yakni wa bait fi wasath al-jannah. Namun, ada penambahan kalimat wa bi baitin fi asfaliha setelah fi a'la al-jannah yang pada dasarnya semakna dengan bi baitin fi rabadh al-jannah. Selain itu, setelah hasuna huluqahu 
terdapat idraj li al-nas yang kemungkinan basar dilakukan oleh 'Atha' ibn Abi Rabah (w.114 H). Sedang periwayat periwayat yang dicurigai melakukan penambahan dan pengurangan diktum dalam versi ini adalah Suwaid Abu Hatim (w. 167 H). Teks hadis ini maqlub yang membawa membawa kepada reduksi subtansi hadis, sehingga dinilai mengandung 'illah.

Varian IV bila dibandingkan dengan varian pertama terdapat perbedaan baik dari segi struktur maupun subtansi teks. Varian ini terdiri dari tiga versi riwayat. Ketiga versi tersebut mencantumkan Anas ibn Malik sebagai periwayat pertama dan Salamah ibn Wardan sebagai periwayat ke-dua.

Versi pertama dari varian ini dicatat oleh al-Tirmidziy. Perbedaan sruktur yang paling mempengaruhi subtansi teks adalah perubahan posisi tarak al-kadzib yang dialihkan ke level rabadh aljannah. Perbedaan struktur lainnya adalah pengeliminasian kalimat ana za'im yang dalam varian-varian sebelumnya disebutkan di awal teks. Lafal buniya lahu menempati posisi bi bait, sedangkan kata aljannah tidak diulang lagi setelah kata fi wasath dan fi a'la, kata ini diwakili oleh dhamir (kata ganti) ha. Menurut penulis perubahan struktur teks hadis ini dilakukan oleh Salamah ibn Wardan. Hadis ini memiliki problem kerancuan lafal yang mengakibatkan perubahan subtansi teks. Dengan ini, dapat dinyatakan bahwa versi ini mengandung 'illah.

Versi ke-dua dikoleksi Ibn Majah. Pada dasarnya versi pertama dan kedua ini identik. Yang membedakan adalah adanya sisipan kata qashrun sebelum fi rabadh al-jannah. Tujuan sisipan ini untuk menjelaskan lafal buniya lahu. Penjelasan ini kemungkinan ditambahkan sendiri oleh Ibn Majah. Sama dengan versi sebelumnya, versi ini pun ber'illah. 
Versi ke-tiga, yang direkam al-Bagawiy benar-benar identik dengan teks al-Tirmidziy. Oleh karena itu, penulis tidak menguraikan analisisnya.

Informasi mengenai sabab al-wurud hadis ini dapat diperoleh dari varian ke-lima. Di awal teks varian ini digambarkan bahwa Nabi menyampaikan hadis tersebut saat duduk bersama para sahabatnya. Nabi menyatakan wajabat-wajabat, yang kemudian dipertanyakan maksudnya oleh para sahabat yang ada di tempat tersebut. Nabi kemudian menyampaikan hadisnya itu.

Dua versi dari varian ini penulis temukan dalam koleksi alHindiy (w. 975 H), yang diduga kuat ia salin dari kitab hadis lain, namun dengan sanad yang kurang lengkap. Salah satu versi ini telah penulis temukan dalam Ma'rifat al-Shahabah karya Abu Na'im yang kemungkinan besar merupakan rujukan dari versi yang dicatat oleh al-Hindiy (lihat versi V). kemungkinan ini diperkuat dengan pencantuman nama Abu Na'im di akhir hadis.

Teks hadis ini bila dibandingkan dengan teks hadis-hadis sebelumnya, paling identik dengan hadis varian IV. Hal ini terjawab jika jalur sanad yang digunakan versi ini disandingkan dengan jalur sanad varian tersebut. Di salah satu mata rantai sanad varian ini juga terdapat nama Salamah ibn Wardan.

Versi yang hanya menyebutkan Malik ibn Aus ibn Hudtsan (w. 91/92 H) sebagai satu-satunya periwayat, memberikan kesan bahwa Malik termasuk dari salah satu sahabat Nabi yang ikut dalam kelompok yang mendengar hadis itu. Namun kesan ini langsung termentahkan jika melihat biografi Malik yang masih diperdebatkan kesahabatannya. Dalam versi ini terdapat lafal annahu kana ma'a Rasul Allah Saw. jalisan, sedang di versi lain kata jalisan ditempatkan sebelum kata Rasul Allah Saw. Perbedaan lainnya adalah kata wajabat disebutkan Nabi hingga tiga kali dengan pernyataan wajabat tsalatsan. Selain itu, dalam versi pertama ditemukan kata wa huwa bathilun yang 
dalam versi ke-dua dicatat dengan wa huwa mubthilun. Perbedaan lainnya adalah dalam versi ke-dua tidak ditemukan kata wa man hasuna khuluqahu buniya lahu fi a'laha. Penulis tidak dapat mengidentifikasi periwayat yang melakukan berbagai perubahan dalam versi ini, karena bila merujuk pada tahun wafat Abu Na'im (w. $430 \mathrm{H}$ ) terlihat bahwa ia kemungkinan menerima hadis tersebut dari Bisyr ibn 'Abisa (w. 230/238 H). Boleh jadi terdapat satu atau dua periwayat sebelum Bisyr yang tidak disebutkan oleh Abu Na'im. Oleh karena itu versi ini belum dapat dianalisis lebih jauh.

Bila hasil analisis sanad dan analisis 'illah hadis disandingkan, maka diduga kuat, lafal yang, setidaknya, paling dekat dengan lafal yang disampaikan oleh Nabi Saw. adalah redaksi yang direkam oleh Abu Daud. Kesimpulan ini diperkuat jika hadis tersebut dipertemukan dengan hadis lain yang juga membahas persoalan tingkatan surga dan amalan yang membawa seseorang menempati tiap tingkatan itu, misalnya hadis diriwayatkan oleh al-Nasa'iy, yang secara struktur lebih dekat dengan varian pertama. Di hadis tersebut, yang juga dimulai dengan lafal ana za'imun, diktum amalan yang membawa ke surga disebutkan terlebih dahulu baru tingkatan surganya.

Kandungan Materi (Content of Text):

Kemungkinan Adanya Syadz

Untuk menguji kemungkinan adanya syadz dalam hadis, penulis mengadopsi teori yang dikembangkan oleh al-Adlabiy, yaitu: tidak bertentangan dengan al-Qur'an, tidak bertentangan dengan hadis lain yang lebih kuat, dan tidak bertentangan dengan fakta sejarah. Namun, dalam prakteknya, penulis hanya menggunakan unsur pertama dan kedua.

Tidak Bertentangan dengan al-Qur'an 
Konsep yang dapat dipahami dari hadis yang sedang diteliti adalah akhlak yang baik merupakan salah satu tiket yang dapat membawa seseorang menduduki posisi terhormat di surga.

Dalam al-Qur'an, surga digambarkan dengan kesenangan yang tidak terbayangkan dan keindahan yang tidak terlukiskan. Kesenangan ini disiapkan bagi mereka yang beriman dan beramal saleh:

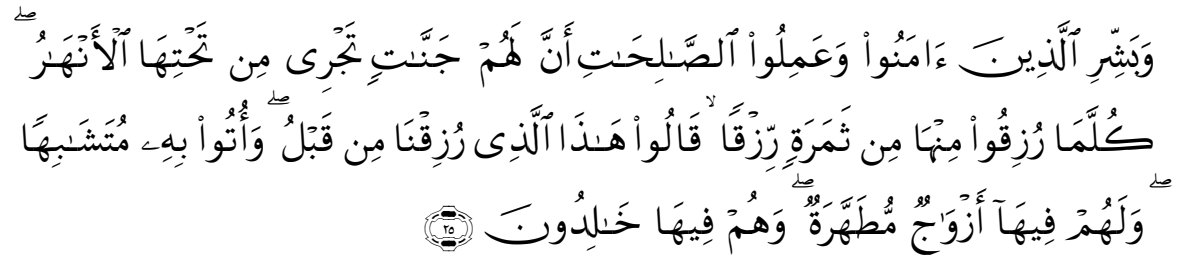

Terjemah:

"Dan sampaikanlah berita gembira kepada mereka yang beriman dan berbuat baik, bahwa bagi mereka disediakan surga-surga yang mengalir sungai-sungai di dalamnya. setiap mereka diberi rezki buah-buahan dalam surga-surga itu, mereka mengatakan : "Inilah yang pernah diberikan kepada kami dahulu." mereka diberi buah-buahan yang serupa dan untuk mereka di dalamnya ada isteri-isteri yang Suci dan mereka kekal di dalamnya"(QS. Al-Baqarah [2]: 25)

Ayat di atas, menurut penulis, dapat dijadikan pendukung bagi hadis yang dibahas. Walaupun unsur akhlak yang baik tidak disebutkan secara eksplisit sebagai modal untuk menduduki salah satu posisi terhormat di surga, tapi sudah tercover di dalam unsur keimanan dan amal shaleh.

Ayat di atas menyebutkan kata jannat yang berarti surgasurga, memberikan kesan bahwa surga itu tidak hanya satu tetapi terdiri dari beberapa, atau bahkan banyak tingkatan. Potret seperti dalam ayat ini, sesuai dengan penggambaran Nabi dalam hadis yang sedang dibahas. Dalam ayat lainnya disebutkan bahwa surga memiliki nama yang bermacam-macam, antara lain: surga Firdaus dan surga 'Adn . 
Uraian di atas memperlihatkan bahwa hadis yang diteliti tidak bertentangan dengan informasi al-Qur'an.

Tidak Bertentangan dengan Hadis yang Dinilai Lebih Kuat

Riwayat yang berkaitan dengan akhlak atau etika begitupun hadis yang berbicara mengenai tingkatan surga, ditemukan banyak bertebaran di hamper semua, kalau tidak ingin dikatakan semua, literatur hadis. Dari sekian banyak hadis itu penulis menemukan sejumlah hadis yang mendukung informasi dari hadis di atas:

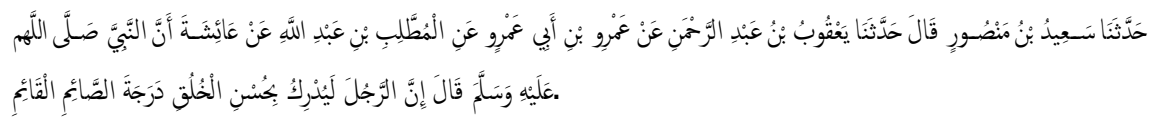

Hadis di atas menjelaskan tentang keutamaan orang yang selalu menjaga akhlaknya. Derajatnya disamakan dengan orang yang berpuasa dan kontinu melaksanakan qiyam al-lail. Mereka yang selalu berusaha memperbaiki akhlak atau etikanya pada dasarnya berjihad melawan nafsunya. Jadi wajar kiranya dijanjikan hunian di level surge tertinggi di akhirat kelak. Dalam hadis lain disebutkan:

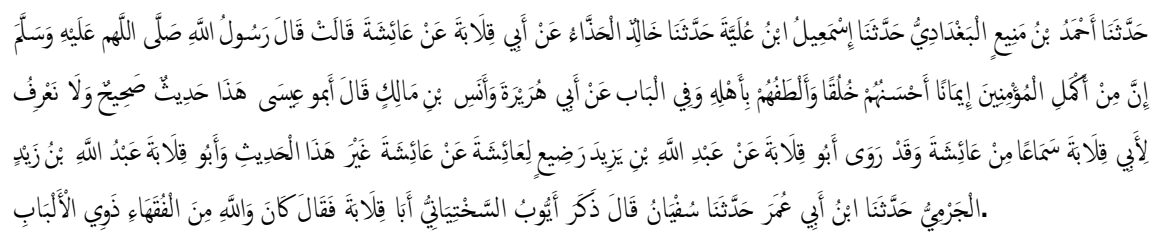

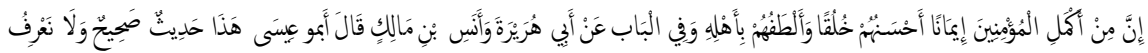

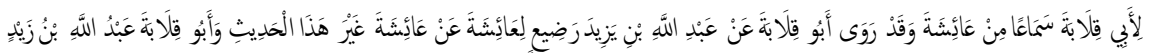

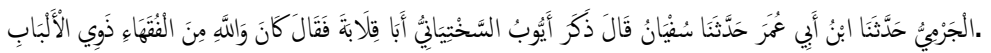

Hadis ini menguraikan bahwa kesempurnaan iman baru dapat terwujud jika dibarengi dengan akhlak dan kebaikan.

Terdapat pula riwayat yang berbicara mengenai tingkatan surga, di antaranya:

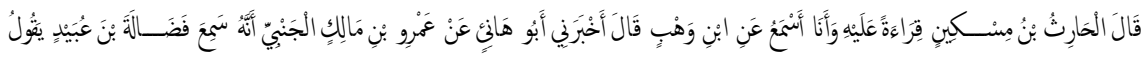

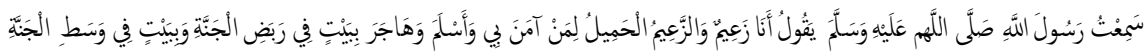




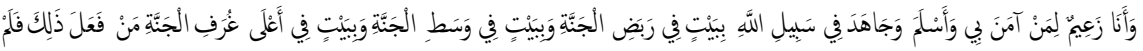

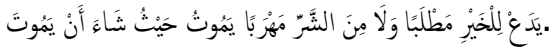

Sekilas terkesan bahwa hadis di atas bertentangan dengan hadis yang dibahas karena perbedaan tampilan amalan yang mendasari posisi seseorang di surga kelak. Namun, yang perlu diingat bahwa Nabi Saw. adalah seorang komunikan ulung. Banyak sabdanya yang terlihat bertentangan karena penyesuaian Nabi terhadap audiens yang dihadapinya. Jadi dapat dinyatakan bahwa hadis di atas tidak bertentangan dengan hadis yang dibahas. Bahkan hadis itu menjadi salah satu pendukung, menunjukkan bahwa telah disiapkan tingkatan surga yang berbea, tergantung amal dan perbuatan manusia selama hidup di dunia.

Dari informasi di atas, dapat dinyatakan bahwa bahwa kandungan hadis yang sedang diteliti sesuai dengan kandungan hadis lain yang juga bernilai valid. Analisis ini menghasilkan kesimpulan bahwa hadis yang sedang diteliti tidak mengandung syadz.

IV. Penutup

Dari uraian di atas dapat disimpulkan sebagai berikut:

Hadis mengenai posisi surga bagi orang yang berakhlak dapat ditemukan di tiga, dari enam, kitab kanonik, yaitu: satu riwayat dari koleksi Abu Daud; satu riwayat dalam catatan al-Tirmidziy; serta satu riwayat lain ditemukan dalam Sunan Ibn Majah. Selebihnya, hadis ini terekam dalam kitab pasca kitab standard (post canonical collection).

Berdasarkan teori yang dikembangkan ulama hadis, sanad hadis, dari dua sampel yang diteliti, Abu Daud dan al-Tirmidziy, yang sedang dibahas memiliki status yang beragam. Sanad Abu Daud berstatus shahih li dzatih sedang sanad al-Tirmidziy berkualitas hasan li ghairih.

Berdasarkan hasil analisa matan, yang kemudian dibandingkan dengan hasil analisa sanad, dapat dinyatakan bahwa 
teks hadis yang kemugkinan besar paling dekat dengan teks yang disabdakan Nabi adalah teks yang direkam oleh Abu Daud dalam Sunannya.

\section{Daftar Pustaka}

Abadiy, al-'Azhim. 'Aun al-Ma'bud: Syarh Sunan Abi Daud, juz III. Beirut: Dar al-Fikr.

Al-Adlabiy, Salahuddin Ahmad. Manhajal-Naqdal-matan 'Inda 'Ulama al-Hadits al-Nabawiy. Beirut: Dar al-Afaq al-Jadidah, t.th.

Ahmad, Arifuddin. Paradigma baru Memahami Hadis Nabi: Refleksi Pemikiran Pembaruan Prof. DR. Muhammad Syuhudi Ismail. Cet. II; Jakarta: MSCC, 2005.

Al-'Alaiy, Dikutip dari Abu Sa'id. Jami' al-Tahshil fi Ahkam al-Marasil, juz I. Cet. II; Beirut: 'Alim al-Kutub, 1986. Dalam Maktabah alSyamilah ver. 13 GB [CD ROM].

Al-Albaniy, Muhammad Nashir al-Din. Shahih al-Targib wa al-Tarhib.

Dalam Maktabah al-Syamilah ver. 13 GB [CD ROM].

Al-'Asqalaniy, Ahmad ibn 'Aliy ibn Hajar Abu al-Fadhl. Tahdzib alTahdzib, juz VIII. Cet. I; Beirut Dar al-Fikr,1984.

. Al-Ishabah fi Tamyiz al-Shahabah, jil. III. Cet. I; Beirut: Dar al-Jil, 1992.

Al-Bagawiy, Abi Muhammad al-Husain ibn Mas'ud. Syarh al-Sunnah, juz VI. Cet. I; Beirut: Dar Kutub al-'Ilmiyyah, 1992.

Al-Baihaqiy, Al-Jalil Abi Bakr Ahmad ibn al-Husain ibn 'Aliy. Al-Sunan al-Kubra, jil. X. Beirut: Dar al-Fikr.

Al-Dzahabiy, Abi 'Abdullah Muhammad ibn Ahmad ibn 'Utsman. Mizan al-I'tidal fi Naqd al-Rijal. Dar al-Fikr.

Hasjim Abbas, Kiritik Matan Hadis: Versi Muhaddisin dan Fuqaha. Cet.

I; Yogyakarta: Teras, 2004. 
Al-Hindiy, 'Alauddin al-Mutqiy ibn Hasan al-Din. Kanz al-'Ummal fi Sunan al-Aqwal wa al-Af'al, juz III. Beirut: Muassasah alRisalah, 1989.

Ismail, M. Syuhudi. Kaedah Kesahihan Sanad Hadis: Telaah Kritis dan Tinjauan dengan Pendekatan Ilmu Sejarah. Cet. II; Jakarta: Bulan Bintang, 1995.

. Metodologi Penelitian Hadis Nabi. Cet. I; Jakarta: Bulan Bintang, 1992.

Al-Mizziy, Abu al-Hajjaj. Tahdzib al-Kamal, juz 27. Cet. I; Beirut: Muassasah al-Risalah, 1980.

______. Tahdzib al-Kamal. Dalam Maktabah al-Syamilah ver 13 GB [CD ROM].

Al-Mubarakfuriy, Muhammad ibn 'Abd al-Rahman ibn 'Abd al-Rahim.

Tuhfat al-Ahwaziy bi Syarh Jami' al-Tirmidziy, juz VI. Beirut:

Dar al-Kutub al-'Ilmiyyah.

Al-Nasa'iy, Abu 'Abd al-Rahman. Sunan al-Nasa'iy, juz X. Maktab alMathbu'at al-Islamiyyah, 1986.

Al-Qazwiniy, Abi ‘Abdullah Muhammad ibn Yazid. Sunan Ibn Majah, jil.

I. Beirut: Dar al-Fikr, 1995.

Al-Raziy, Abu Hatim. al-Jarh wa al-Ta'dil, juz VIII. Cet. I; Beirut: Dar Ihya al-Turats al-'Arabiy, 1952.

Salam, Abu Yahya Badru. Kunci Memahami Hadits Nabi. Cet. I; Tim Pustaka al-Bashirah, 2009.

Shihab, M. Quraish. Tafsir al-Mishbah: Pesan, Kesan, dan Keserasian alQur'an vol. 8. Cet. IV; Jakarta: Lentera, 2005.

Al-Sijistaniy, Abu Daud Sulaiman al-Asy'ats. Sunan Abi Daud, jil. 2. Beirut: Dar al-Fikr, 1994.

Sugiri, Asep. "Wasiat untuk Ahli Waris: Kritik Ekstern dan Intern Otentitas Hadis-hadis Larangan Wasiat untuk Ahli Waris." Dalam M. Amin Abdullah dkk., Metodologi Islamic Studies: 
Mazhab Yogyakarta. Cet. I; Yogyakarta: SUKA Press bekerjasama dengan Jurnal al-Jami'ah, 2007.

Al-Syaibaniy, Ahmad ibn Hanbal Abu 'Abdillah. Musnad Ahmad ibn Hanbal. Dalam al-Maktabah al-Syamilah ver. 13 GB [CD ROM].

Al-Thabariy, Abu Ja'far. Jami'al-Bayan fi Ta'wil al-Qur'an, juz XVIII. Cet. I; Muassasah al-Risalah, 2000.

Al-Tirmidziy, Abu 'Isa Muhammad ibn 'Isa ibn Saurah. Al-Jami' alShahih: Sunan al-Tirmidziy, juz IV. Beirut: Dar al-Kutub al'Ilmiyyah.

Al-Tirmidziy. Al-Jami' al-Shahih: Sunan al-Tirmidziy. Dalam alMaktabah al-Syamilah ver. 13 GB [CD ROM].

Wensinck, A.J. Concordance Et De La Tradition Musulmane. Terj. ke dalam Bahasa Arab Muhammad Fu'ad 'Abd al-Baqiy, alMu'jam al-Mufahras li Alfazh al-Hadits al-Nabawiy, juz II. London: E.J. Brill, 1943. 